\title{
THE CONSTITUTIONAL INSIGNIFICANCE OF FUNDING FOR FEDERAL MANDATES
}

\author{
PATRICIA T. NORTHROP \\ INTRODUCTION
}

In recent years, elected officials, legal commentators, and the national media have focused a great deal of attention on federal statutes that impose obligations on state and local governments without funding the costs of compliance. ${ }^{1}$ State and local officials frequently complain about the severe impact of these unfunded mandates ${ }^{2}$ on their budgets: ${ }^{3}$ the rising cost of such mandates may force states to increase taxes, cut back on existing services, or

1. See, eg., Paul Gillmor \& Fred Eames, Reconstruction of Federalism: A Constitutional Amendment to Prohibit Unfunded Mandates, 31 HARV. J. ON LEGIS. 395 (1994); Rena I. Steinzor, Unfunded Environmental Mandates and the "New Federalism": Devolution, Revolution, or Reform?, 81 MINN. L. REV. 97 (1996); Edward A. Zelinsky, Unfunded Mandates, Hidden Toxation, and the Tenth Amendment: On Public Choice, Public Interest, and Public Services, 46 VAND. L. REV. 1355 (1993); Spencer Rich, GOP Governors Protest Senate Medicaid Bill; States Object that Mandates Could Be Costly, WASH. PoST, Oct. 10, 1995, at A4; Steven Walters, Thompson Warns Against Mandates; He Says Congress May Try to Give States Its Problems But Cut Funding, Mrlwaukee J. \& SENTINEL, July 18, 1995, at A8.

2. As it is commonly used, the term "unfunded mandate" is a double misnomer. First, it usually does not refer exclusively to mandates that are completely unfunded, but rather to any mandate that is inadequately funded-that is, both unfunded and underfunded mandates. See, e.g., Gillmor \& Eames, supra note 1, at 395 n.1; Zelinsky, supra note 1, at 1366 . Second, the label "mandate" is often applied to obligations that states assume voluntarily in order to qualify for federal funds. See, eg., Dan Luzadder, "Forced" Federal Mandates Irk GOP, ROCKY MTN. NEWs, Feb. 28, 1997, at 18A; 2 U.S.C. $\S 1555$ (Supp. I 1995) (defining "Federal mandate," for certain purposes of the Unfunded Mandates Reform Act, as "any provision in statute or regulation or any Federal court ruling that imposes an enforceable duty upon State, local, or tribal governments including a condition of Federal assistance or a duty arising from participation in a voluntary Federal program"); see also David E. Engdahl, The Spending Power, 44 DUKE L.J. 1, 81 (1994) (questioning whether such obligations are truly voluntary, considering states' "dependency on federal funds akin to addiction"). This Note will follow the common practice of using the terms "unfunded" and "mandate" in their broader senses.

3. See, eg., John A. Leinan, The Birds: Regulation of Isolated Wetlands and the Limits of the Commerce Clause, 28 U.C. DAVIS L. REV. 1237, 1242-43 n.23 (1995) (reporting state governors' estimate that federal mandates have been responsible for $80 \%$ or more of new spending in annual budgets.); see also Gillmor \& Eames, supra note 1, at 396 (describing impact on state budgets of federally mandated Medicaid expansions). 
forgo the addition of new services. ${ }^{4}$ Furthermore, unfunded mandates may decrease the political accountability of members of Congress, who create the mandates but place the burden of paying for them-through politically painful methods like raising taxes or decreasing existing services-on state and local officials. ${ }^{5}$ As far as the states are concerned, "unfunded" is a dirty word.

But is there anything constitutionally repugnant about the fact that a particular federal mandate is not accompanied by adequate funding? States claiming that a federal mandate should be struck down on Tenth Amendinent grounds ${ }^{6}$ frequently argue that the inadequacy of funds for inplementation strengthens their claim of unconstitutionality. ${ }^{7}$ For the most part, courts have rejected this argument-but without explaining why. This Note attempts to provide courts with a simple yet previously unexplored reason to disregard funding when assessing the constitutionality of a challenged federal mandate: examining the adequacy of funding would involve the courts in policy issues that must be left to the legislative branch. When a federal mandate is challenged in court, only the structural nature of the mandate, not the adequacy of its funding, should dictate whether the statute will be uplield. ${ }^{8}$

Federal mandates have been around for a long time, but strong complaints and legal challenges from the states are a relatively recent phenoinenon. ${ }^{9}$ Most likely, this activism is tied to the increase in the number of unfunded inandates: ${ }^{10}$ as one commentator has noted, "so long as the federal government supphed states

4. See, e.g., Gillmor \& Eames, supra note 1, at 395, 404-05.

5. See id. at 406; Edward A. Zelinsky, Accountability and Mandates: Redefining the Problem of Federal Spending Conditions, 4 CORNELl J.L. \& PUB. POL'Y 482, 484 (1995).

6. That is, on the grounds that Congress has acted outside the scope of its enumerated Article I powers. See U.S. ConsT. amend. X. ("The powers not delegated to the United States by the Constitution, nor prohibited by it to the States, are reserved to the States respectively, or to the people.").

7. See infra notes $35-41,60-69$ and accompanying text.

8. The Supreme Court las developed several tests for invalidating federal mandates based on the structure or nature of the mandate; these are discussed infra at text accompanying notes $19-24$.

9. See Louis Fisher, The Ubiquity and Ambiguity of Unfunded Mandates, 4 CoRNELL J.L. \& PUB. POL'Y 472, 474-76 (1995).

10. The increase in unfunded mandates, in turn, is usually attributed to the growing federal budget crisis: the federal government has found it necessary to cut spending (or at least reduce increases in spending), yet it continues to pass new regulations even though it cannot supply funds to implement them. See Zelinsky, supra note 1, at 1366 \& n.32. But see id. at 1364 (arguing that there are more complex reasons for the increase in unfunded mandates, which he explains in terms of public choice theory). 
with sufficient funds, complaints were minimal."11 As the number of unfunded mandates has grown, so has the cumulative effect of paying for them; state officials perhaps cannot afford not to challenge some new mandates. The political controversy that surrounds a particular mandate may also influence an official's decision to challenge it.

Two recent politically-controversial and inadequately-funded mandates have prompted a number of constitutional challenges, providing an opportunity to examine courts' treatment of the funding issue. The National Voter Registration Act (NVRA or "Motor Voter" Act) ${ }^{12}$ and the Brady Handgun Violence Prevention Act (Brady Act), ${ }^{13}$ both passed by Congress in 1993, stem from highly charged pohitical issues; neitler provides for full reimbursement of the states' costs of implementation. ${ }^{14}$ The Brady Act is one of the most controversial gun-control measures ever passed in the Umited States, consuming over seven years of congressional debate before finally becoming law. ${ }^{15}$ The Motor Voter Act, which requires states to facilitate voter registration in various ways, seems, on its face, less likely to imvite controversy, but its passage also imvolved partisan politics: the statute was expected to significantly boost Democratic party registration. ${ }^{16}$ These political factors undoubtedly played a role in state officials' decisions to resist the imposition of these two federal mandates by fighting them in court. ${ }^{17}$

11. Fisher, supra note 9 , at 474 .

12. 42 U.S.C. \& 1973gg (1994).

13. 18 U.S.C. \& 922 (1994).

14. The Brady Act authorizes grants to states for use in creating and improving computerized criminal records systems, but does not authorize such funds to be used to cover the costs of performing the background checks required by the Act. See 18 U.S.C. \$ 922 note (Funding for Improvement of Criminal Records). The Motor Voter Act authorizes partial, but not full, reimbursement of states' costs. See 42 U.S.C. § 1973gg.

15. See Ann Devroy, Brady Bill Is Signed into Law; Gun Control Backers Hail Reagan, Clinton, WASH. PosT, Dec. 1, 1993, at A8.

16. See, e.g., ACORN v. Edgar, 56 F.3d 791, 796 (7th Cir. 1995) (noting that the Motor Voter Act "is widely believed to favor Democrats").

17. All six states that formally resisted implementing the Motor Voter Act were led by Republican governors (Pete Wilson of California; Jim Edgar of Illinois; John Engler of Michigan; Tom Ridge of Pennsylvania; David Beasley of South Carolina; and George Allen of Virginia). See STATE Yellow BOOK, Winter 1997, at 40, 125, 222, 373, 392 \& 448. And personal opposition to the Brady Act may have been part of some sheriffs' decisions to challenge that statute. See Frank v. United States, 78 F.3d 815, 834 (2d Cir. 1996) (No. 95-2006) (Miner, J., concurring) ("Sheriff Frank voluntarily took on the CLEO function, apparently for the sole purpose of challenging the Brady Act."), petition 
Ironically, the characteristics of a congressional mandate that are most important to state officials-the level of funding accompanying it and partisan political issues behind $\mathrm{it}^{18}$-are quite unimportant when it comes to deciding the merits of a Tenth Amendment challenge. When evaluating the constitutionality of a federal law imposing duties on the states, courts should be concerned not with the law's funding and political popularity, but rather with how the command to the states is structured.

In its modern federalism cases, the Supreme Court has set forth several rules for determining when a mandate to the states is constitutional. A statute is invalid if it exceeds the scope of the constitutional power under which Congress purports to be legislating. ${ }^{19} \mathrm{~A}$ mandate will also be struck down if it directly imstructs a state legislature to enact particular legislation: "Congress may not simply 'commandee[r] the legislative processes of the States by directly compelling then to enact and enforce a federal regulatory program. " 20 A statute that requires states to choose between two or more regulatory options is unconstitutional if the Constitution does not "authorize Congress to impose either option as a freestanding requirenient." 21 A statute providing financial incentives for a state to adopt a particular policy inay be invalid if the financial inducenrent is "so coercive as to pass the point at which 'pressure turns into coinpulsion." 22 And a state may argue that it

for cert. filed, 64 U.S.L.W. 3856 (June 13, 1996).

However, not all litigation related to the Brady Act involves officials unwilling to carry out the Act. In Roy v. Kentucky State Police, 881 F. Supp. 290 (W.D. Ky. 1995), county sheriffs sued the state police to determine which group would have the privilege of carrying out the Brady Act duties. See id. at 290.

18. As one commentator observed, "The central issue [for politicians at the state level] is not the legitimacy of federal action; it is the relative balance (or imbalance) of federal and state funding." Fisher, supra note 9, at 474. This is not to say that legitimate constitutional concerns are never behind a state government's decision to resist implementing a federal mandate. The degree of intrusiveness of a federal mandate on state autonomy may also prompt state resistance to a federal mandate. See infra notes 20-22 and accompanying text.

19. See, e.g., United States v. Lopez, 115 S. Ct. 1624, 1634 (1995) (holding that GunFree School Zones Act exceeds the scope of Congress' Commerce Clause power); Seminole Tribe v. Florida, 116 S. C. 1114, 1119 (1996) (holding that the Indian Gaming Regulatory Act exceeds Congress' Indian Commerce Clause authority).

20. New York v. United States, 505 U.S. 144, 161 (1992) (alteration in original) (quoting Hodel v. Virginia Surface Mining \& Reclamation Ass'n, 452 U.S. 264, 288 (1981)).

21. Id. at 175-76.

22. South Dakota v. Dole, 483 U.S. 203, 211 (1987) (citations omitted). Dole also 
should be excused from complying with a generally apphicable law because of "failings in the national political process" that led up to the statute's enactment. ${ }^{23}$ However, "[n]o Supreme Court decision has applied the Tenth Amendment to invalidate congressional action on the ground that the action constituted an 'unfunded federal mandate." 24 None of the above tests imvolve an imquiry into whether the amount of funds accompanying the legislation is sufficient, and the lower federal courts should not take it upon themselves to create such a test.

Part I of this Note will describe the duties imposed on the states by the Motor Voter Act and the Brady Act, and will examine lower courts' treatment of the funding issue in cases challenging the constitutionality of those statutes. Part III will demonstrate that the few stateinents the Supreine Court has made on the issue of funding for such mandates militate agaimst treating the presence or absence of funding as a determinative factor im a challenge to a federal inandate. Part III will argue that, as a general rule, the adequacy or inadequacy of funding is not relevant to the constitutional analysis because of a fundamental separation of powers principle: Congress, not the judiciary, is responsible for determinmg the appropriate amount of funds that will accompany federal legislation. Part III will also discuss exceptional circumstances that might justify taking funding into account.

\footnotetext{
states that conditions attached to federal grants must be in pursuit of the general welfare, see id. at 207; that Congress must enable states to exercise their choice knowingly, "cognizant of the consequences of their participation," id. at 207; that the conditions must be related to the federal interest in particular national projects or programs, see id. at 207-08; and that the conditions must not be barred by other constitutional provisions such as the First Amendment, see id. at 208. But see Engdahl, supra note 2, at 62, 81 (observing that conditions attached to federal funds are rarely, if ever, struck down on grounds of coercion or lack of germaneness).

23. Garcia v. San Antonio Metro. Transit Auth., 469 U.S. 528, 554 (1985); see also id. at 550-57 (finding that since structural safeguards of the national political process adequately protect state interests, "judicially created limitations" on federal power are not necessary absent evidence of defects in the political process, id. at 551); New York, 505 U.S. at 160 (limiting Garcia's holding to laws of general applicability). However, the Supreme Court has not made clear exactly what would constitute a "defect" in the political process. See South Carolina v. Baker, 485 U.S. 505, 512-13 (1988).
}

24. Condon v. Reno, 913 F. Supp. 946,965 (D.S.C. 1995). 


\section{LOWER COURTS AND THE FUNDING ISSUE: TWO EXAMPLES}

\section{A. The "Motor Voter" Act}

In 1993, acting pursuant to its Article I, Section 4 power to regulate federal elections, ${ }^{25}$ Congress passed the National Voter Registration Act, ${ }^{26}$ which requires states to allow individuals to register to vote in federal elections when applying for a driver's license. ${ }^{27}$ The Act also requires states to provide for voter registration by mail and at disability and public assistance agencies. ${ }^{28}$ The Act does not provide for full reimbursement of states' costs, although some federal funding may be available to cover a part of the costs incurred by state agencies. ${ }^{29}$

Several states, including California, Illinois, Michigan, Pennsylvania, South Carolina, and Virginia, refused to implement the statute, emphasizing its inadequate funding. ${ }^{30}$ When faced with lawsuits filed by voter organizations and the Justice Departinent, these states claimed that the Motor Voter Act exceeded Congress' Article I powers and thus violated the Tenth Amendinent. ${ }^{31}$ In

25. "The Times, Places, and Manner of holding Elections for Senators and Representatives, shall be prescribed in each State by the Legislature thereof; but the Congress may at any time by Law make or alter such regulations, except as to the Places of chusing Senators." U.S. CONST. art. I, $\S 4$.

26. 42 U.S.C. $\$ 1973 g g$ (1994).

27. See id.

28. See id. \$\$ 1973gg-2 to $\mathrm{gg}-5$.

29. See ACORN v. Miller, 912 F. Supp. 976, 980 n.2 (W.D. Mich. 1995); ACORN v. Ridge, Nos. CIV.A.94-7671, CIV.A.95-382, 1995 WL 136913, at $\neq 5$ (E.D. Pa. Mar. 30, 1995).

30. See ACORN v. Edgar, 880 F. Supp. 1215, 1216-17 (N.D. Ill. 1995), affd, 56 F.3d 791, 798 (7th Cir. 1995); Ridge, 1995 WL 136913, at *1; Wilson v. United States, 878 F. Supp. 1324, 1326 (N.D. Cal. 1995), affd sub nom. Voting Rights Coalition v. Wilson, 60 F.3d 1411, 1416 (9th Cir. 1995), cert. denied, 116 S. Ct. 815 (1996); ACORN v. Miller, 912 F. Supp. 976, 979 (W.D. Mich. 1995); Condon v. Reno, 913 F. Supp. 946, 955 (D.S.C. 1995). The Virginia case, Richmond Crusade for Voters v. Allen, resulted in an unpublished oral ruling. See No. 3:95CV357 (E.D. Va. Oct. 3, 1995). These cases involved lawsuits initiated by voter groups and the Justice Department against state officials, as well as suits by state officials seeking injunctive relief against enforcement of the statute. See, e.g., Condon, 913 F. Supp. at 948.

In Maryland, the NAACP sued the state in order to speed up implementation of the Act; the state has been cooperating with voters' groups and does not contest the Act's validity. See Todd Shields, Groups Sue Maryland Over Motor-Voter Law: Action Says State is Lax on Implementation, WASH. POST, July 23, 1996, at D3.

31. See Wilson, 878 F. Supp. at 1327 (describing California's position that "Congress exceeded the scope of its enumerated constitutional powers by requiring a state to expend resources to carry out a congressional mandate"); Ridge, 1995 WL 136913, at *6 
each case, the district court rejected this defense and upheld the statute. The courts reasoned that the Tenth Amendment did not apply since the Constitution specifically assigns to Congress-and hence does not reserve to the states through the Tenth Amendment-the authority to make or alter state regulations concerning the time, place and manner of federal elections: "[c]onsequently, Congress through the [Motor Voter Act] may directly regulate the state's manner and means of voter registration without invading an area reserved to the states. ${ }^{\prime 33}$ Both the Ninth and the Seventh Circuits, the only appellate courts that have reviewed Motor Voter challenges, affirmed the lower court decisions. ${ }^{34}$

Several of the states involved in these cases had attempted to bolster their Tenth Amendment clainns with arguments or evidence relating to the financial burden imposed by the Motor Voter Act. $^{35}$ In Wilson v. United States, for example, California argued that "Congress exceeded the scope of its enumerated constitutional powers by requiring a state to expend resources to carry out a congressional mandate. ${ }^{236}$ The courts' typical response to such an argument has been to reject it as irrelevant to the constitutional

(noting Pennsylvania's claim that "the NVRA exceed[s] Congress' constitutional grant of authority over the time, place, and manner of elections found in Article 1, Section 4 of the constitution and effectively conscripts state legislatures to implement a federal program in violation of the Tenth Amendment."); Condon, 913 F. Supp. at 963 ("South Carolina's sole claim and defense . . . is that the Act violates the Tenth Amendment."). Although Governor Miller of Illinois ordered state agencies not to comply with the act until federal funds were provided, see Miller, $912 \mathrm{~F}$. Supp. at 980, 983, the opinion in that case did not address funding as a constitutional argument.

32. See U.S. CONST. art. I, $\S 4$.

33. Wilson, 878 F. Supp. at 1328; see also Edgar, 880 F. Supp. at 1219 ("By definition the Tenth Amendnient ... does not apply to powers vested in Congress by the Constitution."); Miller, 912 F. Supp. at 984; Ridge, 1995 WL 136913, at *6-*7 ("It cannot be doubted that [Article I, Section 4] provide[s] a complete code for congressional elections ... to enact the numerous requirenients as to procedure and safeguards which experience shows are necessary in order to enforce the fundamental right involved."); Condon, 913 F. Supp. at 963 ("Because the Constitution specifically delegates to Congress the power to regulate federal elections and the NVRA is limited to federal elections, by its own terms the Tenth Amendment is inapplicable."). The courts also backed up their decisions with references to the Fourteenth and Fifteenth Amendments. See, eg., Edgar, $880 \mathrm{~F}$. Supp. at 1221 (finding that the Fourteenth and Fifteenth Amendments' goal of ending racial discrimination through extension of the right to vote is served through the Motor Voter Act's attempt to increase voter participation by racial minorities).

34. See Edgar, 56 F.3d at 798; Voting Rights Coalition, 60 F.3d at 1416.

35. See Edgar, 56 F.3d at 793; Condon, 913 F. Supp. at 956; Ridge, 1995 WL 136913, at $* 5-* 6$; Wilson, $878 \mathrm{~F}$. Supp. at 1327 .

36. $878 \mathrm{~F}$. Supp. at 1327 . 
analysis, without explaining why this is so. Some courts note the lack of precedent for considering the funding factor as relevant, ${ }^{37}$ but they have not articulated a more specific rationale. For example, when South Carolina "sought to support its constitutional arguments with evidence intended to prove that the [Motor Voter Act] is . . . a costly burden on the State," the court simply held that "all such testimony is irrelevant to determining the constitutionality of the NVRA.."38 Although that court explained that evidence of the cost of implementing the Act was unpersuasive because such costs were balanced by both related and unrelated transfers from the federal government, ${ }^{39}$ it did not elaborate on its assertion that such evidence was constitutionally irrelevant. Other courts, including the Eastern District of Peimsylvamia in ACORN v. Ridge $e^{40}$ and the Seventh Circuit in ACORN v. Ed$\mathrm{gar}^{41}$ followed a similar approach.

\section{B. The Brady Act}

The Brady Act provides for the establishment of an instantaneous national criminal background check system by $1999 .^{42}$ Once that computerized system is available, hicensed firearms dealers will be able to check the eligibility of would-be gun buyers by contacting the system directly from the poimt of sale. ${ }^{43}$ Until that system is in place, an interim provision establishes that the chief law enforcement officer (CLEO) ${ }^{44}$ of the gun buyer's

37. See, e.g., Ridge, 1995 WL 136913, at *8; Condon, 913 F. Supp. at 964.

38. Condon, 913 F. Supp. at 956. See also id. at 957 ("Of course cost is not the touchstone in this constitutional confrontation ....").

39. See id. at 957 (discussing federal funds South Carolina's Department of Social Services received to partially cover costs of Motor Voter implementation as well as large subsidies received by the same agency for programs unrelated to the Motor Voter Act). The possible balancing effects of unrelated federal grants are discussed infra at notes 118-23 and accompanying text.

40. See 1995 WL 136913 at $* 8$.

41. See Edgar, 56 F.3d at 796. The Ninth Circuit in Wilson v. United States also ultimately rejected the state's funding argument, but only after demonstrating great sympathy for the state's plight and suggesting that funding might be relevant in other circumstances-specifically, with regard to legislation enacted under the Commerce Clause. See Wilson, $60 \mathrm{F.3d}$ at 1415 (suggesting that Congress cannot impose financial burdens on states when acting pursuant to its Commerce Clause authority).

42. See 18 U.S.C. \$ 922 note (National Instant Criminal Background Check System).

43. See id.

44. The Brady Act defines CLEO as the "chief of police, the sheriff, or an equivalent officer or the designee of any such individual." 18 U.S.C. $\$ 922(\mathrm{~s})(8)$. All the 
place of residence is responsible for conducting a background check. ${ }^{45}$ Upon receiving notice from a dealer, the CLEO has five business days to make a "reasonable effort" to ascertain whether the transfer would violate any federal, state, or local laws. ${ }^{46}$ The Brady Act does not provide funding to reimburse the states for the resources consumed by the background checks and related duties during the interim period. ${ }^{47}$

Like the Motor Voter Act, the Brady Act has faced constitutional challenges from state officials charged with its implementation. ${ }^{48}$ However, the CLEOs have had somewhat greater success than their Motor Voter counterparts. In five cases, the plaintiffs were able to convince district courts that the provision requiring CLEOs to perform background checks violates the Tenth Amendment. ${ }^{49}$ In striking down the requirement, these courts rehed

CLEOs in the Brady Act challenges discussed in this Note were local sheriffs.

45. See 18 U.S.C. $\$ 922(\mathrm{~s})$. States with their own laws providing for background checks are exempted from the Brady Act. See id. $\S 922(\mathrm{~s})(1)(D)$. In addition to the background checks, the Brady Act's interim provisions also require CLEOs to destroy records related to completed background checks, see id. $\$ 922(\mathrm{~s})(6)(B)(i)$, and to provide explanations to individuals denied handguns if they so request, see id. $\$ 922(\mathrm{~s})(6)(\mathrm{C})$.

46. See 18 U.S.C. $\$ 922(\mathrm{~s})(2)$.

47. The Act does, however, authorize grants for states to use in establishing or improving computerized criminal records systems. See id. $\S 922$ note.

48. See Romero v. United States, 883 F. Supp. 1076 (W.D. La. 1994); Printz v. United States, 854 F. Supp. 1503 (D. Mont. 1994), rev'd sub. nom. Mack v. United States (Mack II), 66 F.3d 1025 (9th Cir. 1995), cert granted sub. nom. Printz v. United States, 116 S. Ct. 2521 (1996); McGee v. United States, 863 F. Supp. 321 (S.D. Miss. 1994), affd sub. nom. Koog v. United States (Koog II), 79 F.3d 452 (5th Cir. 1996), petition for cert filed, 65 U.S.L.W. 3001 (June 25, 1996) (No. 95-2077); Mack v. United States (Mack D), 856 F. Supp. 1372 (D. Ariz. 1994), rev'd, 66 F.3d 1025 (9th Cir. 1995), cert granted sub. nom. Printz v. United States, $116 \mathrm{~S}$. Ct. 2521 (1996); Koog v. United States (Koog D), 852 F. Supp. 1376 (W.D. Tex. 1994), rev'd, 79 F.3d 452 (5th Cir. 1996), petition for cert. filed, 65 U.S.L.W. 3001 (U.S. June 19, 1996) (No. 95-2052); Frank v. United States, 860 F. Supp. 1030 (D. Vt. 1994), rev'd, 78 F.3d 815 (2d Cir. 1996), petition for cert. filed, 64 U.S.L.W. 3856 (June 13, 1996) (No. 95-2006); Frye v. United States, 916 F. Supp. 546 (M.D.N.C. 1995). Unlike the Motor Voter cases, see supra note 30, all the Brady Act cases were initiated by state officials (the CLEOs).

49. See Romero, 883 F. Supp. at 1089; Frank, 860 F. Supp. at 1044; Mack I, 856 F. Supp. at 1383-84; McGee, 863 F. Supp. at 327-28; Printz, 854 F. Supp. at 1519-20.

Although the Brady Act involves the controversial subjects of gun control and the right to bear arms, none of the courts relied on the Second Amendment in their decisions. See, e.g., McGee, $863 \mathrm{~F}$. Supp. at 327 (stating “[t]his lawsuit . . . does not implicate the Second Amendment. This lawsuit involves only the Tenth Amendinent and Article I, Section 8 of the Constitution"). And although the trial courts in Printz, McGee, Mack, and Frank struck down the background check requirement, they upheld the rest of the Brady Act, including provisions that require CLEOs to destroy records related to background checks and to provide explanations for denied landgun transfers. See Printz, 854 
heavily on the Supreme Court's opinion in New York $v$. United States. ${ }^{50}$ In New York, the Court had declared that "federal action [that] would 'commandeer' state governments into the service of federal regulatory purposes" is "inconsistent with the Constitution's division of authority between federal and state governments." ${ }^{.51}$ Although New York was decided in the context of commands to state legislatures, ${ }^{52}$ these courts extended the decision's reasoning to situations involving state executive officials. ${ }^{53}$ One district court upheld all the provisions of the Brady Act against a sheriff's Tenth Amendment challenge, determining that "the Tenth Amendment does not prevent the federal government from iniposing minimal duties on state executive officers."

Three appellate courts have heard Brady Act challenges, and two have upheld the Act. In a consolidated appeal, the Ninth Circuit reversed two district court holdings and ruled that the background check requirement did not violate the Tenth Amendment, reasoning that the Act's obligations represented only a "minimal interference with state functions." 55 The Second Circuit also reversed a lower court ruling and held that the Brady Act was constitutional, on similar grounds. ${ }^{56}$ The Second Circuit distinguished New York as prohibiting only federal commands to state legislatures, and not federal commands to state executives. ${ }^{57}$

F. Supp. at 1519-20; McGee, 863 F. Supp. at 327-28; Mack I, 856 F. Supp. at 1383-84; Frank, 860 F. Supp. at 1044.

50. 505 U.S. 144 (1992) (striking down certain provisions of the Low-Level Radioactive Waste Policy Amendinents Act of 1985).

51. Id. at 175.

52. See id. at 176 ("commandeer[ing] the legislative processes of the States by directly compelling them to enact and enforce a federal regulatory program ... has never been understood to lie within the authority conferred upon Congress by the Constitution.").

53. See McGee, 863 F. Supp. at 325-27 (assuming, without discussion, that New York prohibits commandeering of state executive officials); Frank, 860 F. Supp. at 1041-43 (rejecting government's contention that New York applies only to commandeering of state legislatures); Mack, 856 F. Supp. at 1380-81 (same); Printz, 854 F. Supp. at 1513 (same).

54. See Koog, 852 F. Supp. at 1388; see also id. at 1389 ("[T]he Brady Act does not violate Tenth Amendinent principles because it does not 'commandeer state legislatures,' but instead only places minimal duties upon chief law enforcement officers." Id. at 1389).

55. Mack II, 66 F.3d 1025, 1031 (9th Cir. 1995), rev'g Mack I, 856 F. Supp. 1372 (D. Ariz. 1994) and Printz v. United States, 854 F. Supp. 1503.

56. See Frank v. United States, 78 F.3d 815,830 (2d Cir. 1996) (stating that the burden imposed by the Brady Bill is not "so significant quantitatively that it rises to the level of a constitutional violation"), rev'g $860 \mathrm{~F}$. Supp. 1030 (D. Vt. 1994).

57. See id. at 827-30. This issue is now on appeal to the Supreme Court. See infra note 59. 
However, when the Fifth Circuit addressed the issue in Koog $v$. United States, ${ }^{58}$ it held that the Act's background check requirement-"tantamount to forced state legislation"-does violate the Tenth Amendment. ${ }^{59}$

In arguing that the Brady Act impermissibly infringes upon state sovereignty in violation of the Tenth Amendment, most of the plaintiffs in these cases, like the officials involved in Motor Voter litigation, emphasized the amount of resources consumed by their Brady Act responsibilities. ${ }^{60}$ However, the Brady Act plaintiffs met with greater success in persuading courts that such issues are relevant to the Tenth Amendment analysis. The lack of funding seems to have influenced several of the courts that struck down the background check requireinent.

In Koog, the Fifth Circuit pointed out that local sheriffs' offices faced "fixed and limited law enforcement resources," so that enforcing the Brady Act forced thein to give up other responsibilities that the states might prefer them to carry out. ${ }^{61}$ The court concluded that this use of state resources was a substantial

58. 79 F.3d 452 (5th Cir. 1996), petition for cert. filed 65 U.S.L.W. 3017 (June 25, 1996) (No. 95-2077), rev'g 852 F. Supp. 1376 (W.D. Tex. 1994), and affg McGee v. United States, 863 F. Supp. 321 (S.D. Miss. 1994).

59. The Supreme Court granted certiorari in order to resolve the question of whether congressional "commandeering" of state executives is prohibited by New York $v$. United States. See 64 U.S.L.W. 3829, 3837 (June 17, 1996) (consolidating appeals of the Mack and Printz cases). Oral arguments were heard on December 6, 1996. See id. Although the lack of federal funding issue was not the focus of the Supreme Court appeal, it was mentioned in briefs and oral argument. See Supreme Court Official Transcript, Printz, Nos. 95-1478, 95-1503, 1996 WL 706933, at *39,*41-42, *47 [hereinafter Printz Transcript]; Brief for the United States, Nos. 95-1478, 95-1503, 1996 WL 595005, at *32, *39 [hereinafter United States Brief]; Brief for the Petitioner [Printz], No. 95-1478, 1996 WL 464182, at *18 [hereinafter Printz Brief].

At the time of publication of this Note, the Supreme Court had not yet announced its decision. The theory advanced in this Note, however, does not depend on the Court holding one way or the other in the Printz case. Rather, this Note asserts only that regardless of whether the Court upholds or strikes down the Brady Act's requirements, its decision should not turn on the fact that federal funding is not provided to cover the cost of conducting the background checks.

60. See Mack I, 856 F. Supp. at 1375 ("Mack maintains ... that he does not have the personnel or funds to [conduct background investigations]."); Printz, 854 F. Supp. at 1507 ("Plaintiff testified that enforcement of the Act forces him to reallocate already limited resources such that he is unable to carry out certain duties prescribed by state laws."); Romero, 853 F. Supp. at 1085-86 ("Sheriff Romero argues . . . that [he] faces a severe funding shortage."); Koog I, 852 F. Supp. at 1381 ("Sheriff Koog argues that he must expend scarce resources of his office on background checks.").

61. 79 F.3d at 460 . 
burden: "We do not consider it a minimal interference when a local sheriff or chief of police is offered no choice but to devote purely local manpower and monetary resources to check the backgrounds of countless applicants for handgun purchases." 62 The United States District Court of Montana, in Printz v. United States, ${ }^{63}$ similarly eniphasized the "great effort and the expenditure of unfunded resources" required to implenient the Brady Act, noting the deleterious effect on other programs and activities the state might be interested in providing for its citizens. ${ }^{64}$ The United States District Court of Arizona, in Mack $v$. United States, ${ }^{65}$ also found it noteworthy that "the state is forced to expend time and resources toward implementation of the Act." ${ }^{266}$ The Western District of Louisiana in Romero v. United States ${ }^{67}$ seemed to come closest to basing its decision on the lack of funding. That court was extremely sympathetic to the plight of the sheriff's office, repeatedly referring to its "serious funding shortage." contrast, the Second and Ninth Circuits, which upheld the entire Brady Act, found that the effort required and the resources consumed by the Act were minimal and rejected the sheriffs' claims. ${ }^{69}$

\section{FUNDING ISSUES IN THE SUPREME COURT}

\section{A. The Insignificance of Funding in Tenth Amendment Cases}

Several of the U.S. Supreme Court's ntodern federalisnı cases liave touched on the question of whether inadequate funding can, by itself, nrake a federal mandate unconstitutional. In each case, the Court has rejected the notion that funding is a determinative factor in assessing the constitutionality of a federal statute. ${ }^{70}$

62. Id. at 461 .

63. 854 F. Supp. 1503.

64. See id. at 1514-15, 1517.

65. 856 F. Supp. 1372 (D. Ariz. 1994).

66. Id. at 1381; see also Frank, $860 \mathrm{~F}$. Supp. at 1032.

67. 883 F. Supp. 1076 (W.D. La. 1994).

68. Id. at $1079,1080,1085$.

69. See Frank v. United States, 78 F.3d 815, 830-31 (2d Cir. 1996); Mack II, 66 F.3d at 1031-32; see also Koog I, 852 F. Supp. at 1388-89 (discussed supra note 54 and accompanying text).

70. Members of the Supreme Court have held widely varying views on what, if any, restrictions the Tenth Amendment places on federal action. Compare, for example, Justice O'Connor's majority opinion in New York v. United States, 505 U.S. 144, 156 (1992) 
In National League of Cities v. Usery, ${ }^{71}$ the Court addressed the constitutionality of the 1974 amendments to the Fair Labor Standards Act, which extended the statute's minimum wage and maximum liour provisions to state employees. ${ }^{72}$ The majority noted that while the challenged amendments would cost the states a significant amount of money, cost was not the dispositive factor. ${ }^{73}$ Although Justice Brennan disagreed witl the outcome of the case, he agreed with the majority that cost alone should not be determinative. ${ }^{74}$

The insignificance of compliance costs was again noted in FERC v. Mississippi ${ }^{75}$ when the Court reviewed the constitutionality of the Public Utility Regulatory Policies Act of 1978 (PURPA) ${ }^{76}$ PURPA required state utility commissions to enforce standards promulgated by the Federal Energy Regulatory Commission (FERC) and to follow certain rulemaking procedures. ${ }^{77}$ The Court noted Mississippi's claim "that PURPA's requirements must fall because compliance will impose financial burdens on the States."78 The Court, lowever, was unconvinced: "in a Tenth Amendment challenge to congressional activity, 'the determinative

(finding that the Tenth Amendment provides affirmative limits on congressional power) and Justice Rehnquist's majority opinion in National League of Cities v. Usery, 426 U.S. 833, 842-43, 852 (1976) (same), with Justice Brennan's dissent in National League of Cities, 426 U.S. at 856 (stating that the "political process" set forth in the Constitution adequately protects state sovereignty, and thus there is no need to read the Tenth Amendment as providing additional substantive protection for the states), and Justice Blackmun's majority opinion in Garcia v. San Antonio Metro. Transit Auth., 469 U.S. 528, 552 (1985) (same). Yet even justices holding very different views of the Tenth Amendment have been able to agree that the financial impact of a federal mandate, by itself, is not a determinative factor in the constitutional analysis. See infra text accompanying notes 71-74 (noting dissenting Justice Brennan's agreenient with National League of Cities majority on this issue); infra text accompanying notes 84-91 (noting similar views of Garcia majority and dissent on this point).

71. 426 U.S. 833 (1976).

72. See id. at 836 .

73. See id. at 846-49, 851-52. Ultimately the outcome in National League of Cities hinged on the Court's finding that the statute interfered with "the States' freedom to structure integral operations in areas of traditional governmental functions," id. at 852, a test the Court lsas since abandoned, see Garcia, 469 U.S. at 546-47.

74. See National League of Cities, 426 U.S. at 874 n.12 (Brennan, J., dissenting) ("My Brethren's reluctance to rely on the cost of compliance to imvalidate this legislation is advisable.").

75. 456 U.S. 742 (1982).

76. 16 U.S.C. § $2601-45$ (1994).

77. See 456 U.S. at 759.

78. Id. at 770 n.33. 
factor ... [is] the nature of the federal action, not the ultimate economic impact on the States. " "79

The financial burden argument has also failed in Tenth Amendment cases involving federal regulation of private conduct that happens to have indirect effects on state coffers. The plaintiffs in Hodel v. Virginia Surface Mining \& Reclamation Association ${ }^{80}$ claimed that a statute imposing detailed regulations on the mining industry violated the Tenth Amendment because it would have adverse effects on Virginia's economy (such as a reduction in the tax base) ${ }^{81}$ In response, the Court stated that "even if it is true that the Act's requirements will have a measurable impact on Virginia's econoiny, this kind of effect, standing alone, is insufficient to establish a violation of the Tenth Amendment." Court summarily rejected the plaintiffs' assertion that "an adverse impact on state and local economies is a barrier to Congress' exercise of its power under the Commerce Clause to regulate private activities affecting interstate commerce." ${ }^{93}$

Just as inadequate funding is not, by itself, sufficient grounds for striking down a statute, the converse is also true: the presence of generous funding does not coinpel a conclusion of constitutionality. In Garcia v. San Antonio Metropolitan Transit Authority, ${ }^{84}$ the Supreme Court again considered the constitutionality of amendments to the Fair Labor Standards Act (FLSA), ${ }^{85}$ this time upholding the act as applied to the states. The Court noted that the federal government, in separate legislation, lad provided the San Antonio transit authority with significant financial assistance, ${ }^{86}$ but stated that the constitutionality of the challenged

79. Id. (alteration in original) (quoting Hodel v. Virginia Surface Mining \& Reclamation Ass'n, 452 U.S. 264, 292 n.33 (1981)).

80. 452 U.S. 264.

81. See id. at 292 n.33.

82. Id.

83. Id. The Supreme Court has made no distinction, for purposes of the funding issue, between cases where Congress is attempting to regulate state govemmental activity directly, as in $F E R C$, and those in which Congress is regulating private activity with an alleged indirect effect on state funds, as in Hodel. The Court has found funding equally insignificant in both situations: in fact, the FERC Court quoted Hodel when it stated that the determinative factor was the nature of the federal action rather than the ultinate economic impact on the states. See supra note 79 and accompanying text.

84. 469 U.S. 528 (1985).

85. 29 U.S.C. $\$ 203$ (1994). The Court had previously examined FLSA in National League of Cities, discussed supra at text accompanying notes 71-74.

86. See 469 U.S. at 555; see also infra notes 112-14 and accompanying text. 
statute did not depend on that fact: "Our references to [the Urban Mass Transit Act, a federal statute supplying the states with funds for public transportation] are not meant to imply that regulation under the Commerce Clause must be accompanied by countervailing financial benefits under the Spending Clause. The application of the FLSA to [the San Antonio Metropolitan Transit Authority] would be constitutional even liad Congress not provided federal funding." 87 Rather, Garcia's outcome depended on the majority's finding that there was no defect in the political process leading to the enactment of the statute. ${ }^{88}$ The majority used the existence of countervailing federal funds as evidence that the political process liad worked in this case, and that the states lad succeeded in having their financial interests protected in Congress. ${ }^{89}$

Dissenting Justice Powell, joined by Justices Rehnquist, O'Connor, and Chief Justice Burger, criticized the majority for paying even this much attention to the funding issue. ${ }^{90}$ These justices asserted that evidence of federal grants to the states was conipletely irrelevant to the Tenth Amendinent analysis: "Regardless of the willingness of the Federal Government to provide federal aid, the constitutional question remains the same: whether the federal statute violates the sovereign powers reserved to the States by the Tenth Amendinent." ${ }^{\prime 91}$ Thus, all nine Justices agreed that the presence of federal funding did not control the outcome of the case, although the majority felt it liad soine relevance for their reasoning.

In this way, the constitutional irrelevancy of funding is a twoway street. Congress' failure to compensate the states for a mandate's negative impact on state treasuries does not autoinatically render the act unconstitutional, as shown by National League of Cities, FERC, and Hodel..$^{92}$ Likewise, the provision of generous federal funds will not make an otherwise unconstitutional act ${ }^{93}$

87. 469 U.S. at 555 n.21.

88. See id. at 550-57.

89. See id. at 555 ("[T] he status of public mass transit simply underscores the extent to which the structural protections of the Constitution insulate the States from federally imposed burdens.").

90. Id. at 566 n.10 (Powell, J., dissenting).

91. Id.

92. See supra text accompanying notes 71-83.

93. Unconstitutional, for example, because the statute violates one of the tests described supra notes $19-23$ and accompanying text. 
constitutional, as demonstrated by Garcia; ${ }^{94}$ the federal governinent cannot purchase intrusions into state sovereignty at any price.

\section{B. Unfunded Mandates Do Not "Indirectly Commandeer" State Legislatures in Violation of the Constitution}

The argument has been made in some of the Brady Act and Motor Voter cases that forcing states to pay for a federal mandate constitutes indirect commandeering of state legislatures in violation of the Tenth Amendment. ${ }^{95}$ Specifically, the argument runs as follows: if a mandate does not provide sufficient funds to cover the cost of its implementation, the state must fund it by giving up or decreasing other services, or by raising taxes. By thus forcing the state legislature to allocate funds for activities that Congress, rather than the state legislature, has identified as important, Congress "mdirectly commandeers the legislative processes of the state" in violation of New York $v$. United States. ${ }^{96}$

This reasoning is an unwarranted extension of New York. The claim that a federal law is invalid if it indirectly requires state legislatures to allocate funds for implementation has already been rejected by the Supreme Court. In South Carolina v. Baker, ${ }^{97}$ the Court upheld Section 310 of the Tax Equity and Fiscal Responsibility Act of $1982,,^{98}$ which required that long-term bonds issued

94. See supra text accompanying notes $84-89$. Of course, states may be less likely to complain about infringeinents on state sovereignty when a federal mandate is accompanied by generous funding. See supra text accompanying note 11.

95. See New York, 505 U.S. at 161 (holding that a congressional attempt to "commandeer" state legislatures-i.e., "directly compelling them to enact . . . a federal regulatory program"-is unconstitutional) (quoting Hodel v. Virginia Surface Mining \& Reclamation Ass'n, 452 U.S. 264, 288 (1981)).

96. Printz v. United States, 854 F. Supp. 1503, 1513 (D. Mont. 1994), rev'd sub. nom. Mack v. United States (Mack II), 66 F.3d 1025 (9th Cir. 1995), cert. granted sub. nom. Printz v. United States, 116 S. Ct. 2521 (1996); see also Koog II, 79 F.3d 452, 458-60 \& n.7 (5th Cir. 1996) (stating that the Brady Act in effect legislates new job duties for state officials and amends state criminal codes), petition for cert. filed, 65 U.S.L.W. 3001 (June 19, 1996) (No. 95-2052); Printz Brief, supra note 59, at *21-22 (same); ACORN v. Ridge, Nos. CIV.A.94-7671, CIV.A.95-382, 1995 WL 136913, at *6 (E.D. Pa. Mar. 30, 1995) (rejecting Pennsylvama's argument that the Motor Voter Act "effectively conscript[s] state legislators to implenient a federal program in violation of the Tenth Aniendment").

97. 485 U.S. 505 (1988).

98. 26 U.S.C. § 103(j) (1982) (repealed 1988). The content of this section is now embodied in 26 U.S.C. $\$ 149$ (a) (1994). 
by state and local governments be in registered form in order to qualify for a federal incoine tax exemption for interest earned on the bonds. ${ }^{99}$ The National Governors' Association (as intervenor) contended that Section 310 commandeered state legislatures in violation of the Tenth Amendment "because many state legislatures had to amend a substantial number of statutes in order to issue bonds in registered form and because state officials had to devote substantial effort to determine how best to implement a registered bond system." 100 The Court rejected this argument:

Such 'commandeering' is . . a an inevitable consequence of regulating a state activity. Any federal regulation deinands coinphance. That a State wishing to engage in certain activity must take adininistrative and sometimes legislative action to comply with federal standards regulating that activity is a commonplace that presents no constitutional defect. ${ }^{101}$

The Court further observed that under the National Governors' Association's theory, "any State could immunize its activities from federal regulation by simply codifying the manner in which it engages in those activities."102 If a mandate is to be struck down under an extension of $\mathrm{New}$ York's prohibition on commandeering, it would have to be under the principle that Congress cannot coinmandeer state executive branch officials to carry out federal laws ${ }^{103}-$ not on a theory that any action that can be character-

99. See 485 U.S. at 512-13.

100. 'Id. at 514.

101. Id. at 514-15. Although Baker was decided before New York's holding that federal commandeering of state governments is unconstitutional, the rule against commandeering had already been articulated in other Supreme Court cases by the time Baker was decided. See FERC v. Mississippi, 456 U.S. 742, 761-62 (1982) (observing that "this Court never has sanctioned explicitly a federal command to the States to promulgate and enforce laws and regulations"); Hodel v. Virginia Surface Mining \& Reclamation Ass'n, 452 U.S. 264, 288 (1981) (finding Surface Mining Act constitutional in part because "there can be no suggestion that the Act commandeers the legislative processes of the States by directly compelling them to enact and enforce a federal regulatory program"); see also New York, 505 U.S. at 161 (citing FERC and Hodel in support of New York's holding).

102. Id. at 515 .

103. While the Supreme Court has not yet explicitly stated that commandeering of state executives is unconstitutional, it is possible to infer such a principle froin New York. See supra text accompanying notes 50-55 (discussing lower court's reasoning in Brady Act cases that New York prohibits commandeering of state executive branch officials); see also Saikrishna Bangalore Prakash, Field Office Federalism, 79 VA. L. REV. 1957 (arguing that Framers "envisioned federal commandeering of state executive officers," id. at 1960). 
ized as "indirect commandeering" of state legislatures is invalid.

In sum, "there is no law to support [the] position that because a state inust bear the cost, the legislation therefore fails to pass constitutional muster." 104 The Supreme Court cases discussed in this section demonstrate that courts must look to the nature of the federal action at issue without regard to whether the states bear the financial burden of that action. There is no precedent for considering the absence or alleged inadequacy of funding as a determinative factor in the constitutional analysis of a federal mandate; in fact, the Court has consistently rejected the suggestion that the level of funding should be a determinative factor.

However, no majority opinion of the Court has ever discussed why funding carries so hittle weight in the constitutional analysis. ${ }^{105}$ There is in fact a very good reason not to take the level of funding into account when conducting the constitutional analysis based on the separation of powers doctrine: examining the level of funding provided and evaluating its sufficiency would involve the courts in issues of policy that must be left to the legislature, and thus courts must avoid making such an inquiry. Part III discusses this rationale in greater depth.

\section{A Separation of Powers Basis for Treating Funding AS CONSTITUTIONALLY IRRELEVANT}

\section{A. Funding: A Question for Congress, Not the Courts}

Under the separation of powers doctrine, the fact that funding is or is not provided is not merely inconclusive; it should not be considered at all in a Tenth Amendment challenge. Matters of funding "raise not constitutional issues but questions of policy. They relate to the wisdom, need, and effectiveness of a particular project. They are therefore questions for the Congress, not the courts. ${ }^{.106}$

And the Court may very well announce a rule against federal commandeering of state executive officials in its forthcoming Printz decision. See supra note 59 (discussing the Printz Supreme Court appeal).

104. ACORN v. Ridge, Nos. CIV.A.94-7671, CIV.A.95-382, 1995 WL 136913, at *8 (E.D. Pa. Mar. 30, 1995); see also Condon v. Reno, 913 F. Supp. 946, 965 (D.S.C. 1995) ("No Supreme Court decision has applied the Tenth Amendment to invalidate congressional action on the ground that the action constituted an 'unfunded federal mandate."').

105. The lower courts that rejected the financial burden arguinent also have failed to provide satisfactory rationales for doing so. See supra notes 37-40 and accompanying text.

106. National League of Cities v. Usery, 426 U.S. 833, 874 n.12 (1976) (Brennan, J., 
The Constitution specifically assigns to Congress the power to spend money from the federal treasury. ${ }^{107}$ Decisions regarding how much to spend for a particular law fall within the realm of policy issues left to congressional discretion. For each new unfunded mandate, Congress decides whether to provide funding, and if so, low much to provide. Both these determinations are policy issues that should be left to Congress and should not be reviewed by the courts. As the Supreme Court has noted time and again, its disagreement with a policy choice made by Congress is not sufficient grounds for invalidating a federal statute so long as there is a rational basis for the law: "judicial intervention is generally unwarranted no matter how unwisely [the court] may think a political brancli has acted." 108 The amount Congress lias cliosen to provide in any given case may reflect important decisions about low it wants the mandate to be implemented. For example, Congress may have intentionally allocated a fairly small amount of funds in order to encourage states to find the most cost-effective means of implementing the mandate. ${ }^{109}$ Problems with determining how much funding is enough are compounded by the difficulties in determining how much it costs to implement the mandate. ${ }^{110} \mathrm{~A}$ court slould not substitute its findings on any of these

dissenting) (quoting Oklahoma ex rel. Phillips v. Atkinson Co., 313 U.S. 508, 527 (1941)). This comment by Justice Brennan, tucked away in a footuote, is perhaps the only reference in Supreme Court jurisprudence to the separation of powers implications of including funding as a factor in Tenth Amendment analysis (or for that matter, the only attempt to provide any sort of rationale at all for rejecting financial burden claims).

107. See U.S. CONST. art. I, $\& 8$ (Spending Clause, conferring on Congress the power "to pay the Debts and provide for the common Defense and general Welfare of the United States"); id. art I, $\S 9$ ("No money shall be drawn from the Treasury, but in Consequence of Appropriations made by Law.").

108. Vance v. Bradley, 440 U.S. 93, 97 (1979); see also FCC v. Beach Communications, 508 U.S. 307, 313-14 (1993) ("Where there are 'plausible reasons' for Congress' action, 'our inquiry is at an end."'); Hodel v. Virginia Surface Mining \& Reclamation Ass'n, 452 U.S. 264, 276 (1981) ("The judicial task is at an end once the court determines that Congress acted rationally in adopting a particular regulatory scheme."); Buckley v. Valeo, 424 U.S. 1, 83 (1976) (discussed further infra notes 117-24 and accompanying text); National League of Cities, 426 U.S. at 881 (Stevens, J., dissenting) ("My disagreement with the wisdon of this legislation may not, of course, affect my judgment with respect to its validity.").

109. See Fisher, supra note 9, at 477 (stating that providing full federal funding and allowing states to spend the maximum would discourage exploration of inexpensive remedies).

110. See id. at $476-77$. 
issues for those of Congress: "[A] legislative choice is not subject to courtroom factfinding."111

Furthermore, there are broader, systemic considerations at work in legislative funding decisions. Congress may have declined to authorize funds for a specific mandate because it has already transferred large sums of money to the states for related activities (imcluding grants for activities not mandated by the federal government, which Congress is not obligated to subsidize) $)^{112}$ and feels that those sums help balance out the cost of implementing the mandate, though they are not specifically provided for implementation. ${ }^{113}$

If courts were to review Congress' decision regarding the appropriate level of funding for a particular mandate, they could not, in all fairness to Congress, ignore the balancing effect of these other transfers to the states. ${ }^{114}$ But the consequences of the fed-

111. Beach Communications, 508 U.S. at 315.

112. For instance, the Violent Crime Control Appropriations Act of 1995, passed separately from the Brady Act, provided the states with nearly $\$ 450$ million for general law enforcement purposes. See tit. 8, Pub. L. No. 103-317, 108 Stat. 1777 (1994).

113. For example, the Brady Act authorizes millions of dollars in grants to the states for improving computerized criminal record systems (and the 1995 Violent Crime Control Appropriations Act, tit. 8, 108 Stat. 1777, allocated $\$ 100$ milhon for this purpose), although it does not authorize funds to cover the cost of conducting the background checks. See 18 U.S.C. $\S 922$ note (National Instant Criminal Background Check System).

The court in Condon noted that South Carolina's Department of Social Services, which the state argued would face significantly increased costs as a result of the Motor Voter Act, was "heavily subsidized by the federal government" for costs related to the Motor Voter Act as well as for completely unrelated costs like food stamps. See Condon v. Reno, 913 F. Supp. 946, 956-57 (D.S.C. 1995). See also Garcia v. San Antonio Metro. Transit Auth., 469 U.S. 528, 555. As the Court observed in Garcia (in which the city of San Antonio sought relief fron the minimum wage and overtime pay requirements of the Fair Labor Standards Act):

Congress has not simply placed a financial burden on the shoulders of States and localities that operate niass-transit systems, but has provided substantial countervailing financial assistance as well, assistance that may leave individual mass-transit systems better off than they would have been had Congress never intervened at all in the area.

Id. The Court pointed out that "[w]lhen Congress first subjected state mass-transit systems to FLSA obligations in 1966, and when it expanded those obligations in 1974, it simultaneously provided extensive funding for state and local mass transit" with the Urban Mass Transit Act and that Congress had, over a 20-year period, allocated over $\$ 20$ billion to states and localities in mass transit aid. Id.

114. Cf. Garcia, 469 U.S. at 555 (noting that although Congress has subjected states and numicipalities to minimum wage requirements for nass-transit employees, it also provides substantial funding to these mass-transit systems, thus balancing the effect of the FLSA requirements). Similarly, in Condon, the district court noted: 
eral courts examining the big picture in these cases to see if overall levels of funding are adequate would be even worse than the effects of examining whether the funding directly tied to a particular mandate is sufficient. The courts would then be reviewing an even broader array of congressional decisions-inquiring into what programs Congress has chosen to fund, and why-and perhaps, in effect, telling Congress it should not be subsidizing as many state activities as it now does. ${ }^{115}$ This is not the business of the federal courts. In reviewing congressional mandates to the states, courts should not review the pohicy choices made by Congress, because the legislature is the primary institution charged with making such choices under the Constitution. Rather, under rational basis review, the courts must defer to Congress on these matters. ${ }^{116}$

[A]lthough South Carolina complains that it would be required to bear the entire cost of the NVRA, testimony indicated that many of the mandated voter registration agencies are heavily subsidized by the federal governinent .... Of course cost is not the touchstone in this constitutional confrontation, but South Carolina's failure even to attempt to examine possible offsetting savings-or even possible net savings overall-seriously undermines South Carolina's claimed fiscal concerns about the NVRA.

913 F. Supp. at 956-57.

115. Not only is this approach constitutionaily impermissible, it is unlikely to benefit the states in the long run. If the federal courts did decide to look at funding for particular mandates and then determined that it was insufficient, Congress might respond by providing funding for those mandates at the expense of other transfers to the states, that is, by decreasing the grants it now gives to the states for non-mandated activities (such as the general law enforceinent grants described supra at note 112). As a result, state treasuries would likely enjoy no net gain, and might even suffer a net loss.

116. See supra notes 107-111 and accompanying text. The argument against intensive judicial review of congressional funding decisions could also be phrased in terms of the political question doctrine, a combination of the justiciability and separation of powers theories. See ERWIN CHEMERINSKY, Federal JuRISDICTION § 2.6.1-.2 (2d ed. 1994). Under the political question doctrine, certain subject areas are deemed non-reviewable. See id. § 2.6.1. In the seminal political question case of Baker v. Carr, 369 U.S. 186 (1962), the Supreme Court listed several characteristics of a political question:

Prominent on the surface of any case held to involve a political question is found a textually demonstrable constitutional commitment of the issue to a coordinate pohitical department; or a lack of judicially discoverable and manageable standards for resolving it; or the impossibility of deciding without an imitial policy determination of a kind clearly for nonjudicial discretion; or the inpossibility of a court's undertaking independent resolution without expressing lack of the respect due coordinate branches of government ....

Id. at 217. Each of these issues is implicated in the case of congressional spending and funding decisions. However, given the vagueness and uncertainty surrounding the political question doctrine, see CHEMERINSKY, supra, § 2.6.1., and the fact that the Supreme Court has not specifically identified Spending Clause controversies as non-justiciable political questions, see $i d$, this Note focuses on general separation of powers principles, rather than advocating a political question approach. 
The Supreme Court has not yet applied a separation of powers rationale in the context of a congressional decision regarding funding of a federal mandate. It has, however, invoked separation of powers principles and recognized the need to defer to the legislative branch in other settings where Congress has established monetary levels that Congress decided were appropriate. In Buckley v. Valeo, ${ }^{117}$ the Court was called upon to assess the constitutionality of various provisions of the Federal Election Campaign Act. ${ }^{118}$ The provisions challenged under the First Amendment included the recordkeeping and disclosure requirements of the Act, which were attacked as overbroad. The Act required pohtical committees to keep records of imdividuals contributing as little as $\$ 10$, and reports of those contributing over $\$ 100$ were required to be filed with the Federal Election Commission. ${ }^{119}$ In spite of the significant First Amendinent interests at stake-poitical speech and freedom of association-the Court declined to consider the possibility that Congress had set the thresholds too low. ${ }^{120}$ Although the Court agreed that the low thresholds had potential to deter political participation and felt that there was "little in the legislative history to indicate that Congress had focused carefully on the appropriate level at which to require recording and disclosure,"121 these observations were not sufficient to warrant holding the thresholds unconstitutional. Rather, the Court recognized that it must defer to Congress on the issue: "[W] cannot require Congress to establish that it has chosen the highest reasonable threshold. The line is necessarily a judgmental decision, best left in the context of this complex legislation to congressional discretion." 122

The context of the Buckley decision is analogous to the issues a court faces when asked to consider the impact on states of low (or nonexistent) levels of funding for federal mandates. In both cases, a court is asked to review the level of money that Congress felt was appropriate for achieving its goals. In Buckley, Congress apparently felt that the $\$ 10$ and $\$ 100$ thresholds were fair means of preventing corruption, ${ }^{123}$ and the Supreme Court refused to

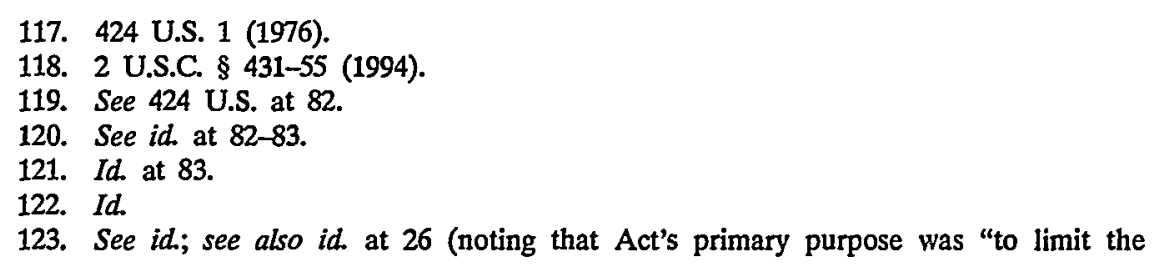


review that decision in the absence of evidence that the limits designated were "wholly without rationality."124 In the federal mandate cases, Congress has felt it appropriate to provide certain funds (or, in some cases, no funds at all), and the courts similarly must defer to Congress' discretion to establish the appropriate monetary amounts on this issue.

\section{B. A Possible Exception: Mandates that Threaten States' Existence}

It is conceivable that, at some point, a federal mandate might impose such an overwhelming financial burden on a state as to threaten the state's very existence. ${ }^{125}$ If the obligations created by the Motor Voter Act or Brady Act were so extensive and expensive that the states were unable to carry on any functions other than voter registration or gun control enforcement, then it would be appropriate to consider the mandate's implementation costs and the lack of federal funding for those costs in assessing its constitutionality. Only when the very act of complying with the statute would render the state unable to carry on any other func-

actuality and appearance of corruption resulting from large individual financial contributions").

124. Id. at 83 .

125. The Supreme Court has long recognized some degree of state sovereignty, including the need to ensure that the states' continued existence as states is not threatened:

[T]he preservation of the States, and the maintenance of their governments, are as much within the design and care of the Constitution as the preservation of the Union and the maintenance of the National government. The Constitution, in all its provisions, looks to an indestructible Union, composed of indestructible States.

New York v. United States, 505 U.S. 144, 162 (1992) (quoting Texas v. White, 74 U.S. (7 Wall.) 700, 725 (1868)). See also Metcalf \& Eddy v. Mitchell, 269 U.S. 514, 523 (1926) (stating that "neither government may destroy the other nor curtail in any substantial manner the exercise of its powers"). The inore difficult question has been how to protect such sovereignty. See, e.g., Garcia v. San Antonio Metro. Transit Auth., 469 U.S. 528, 547 (1985) ("What has proved problematic is not the perception that the Constitution's federal structure imposes limitations on the Commerce Clause, but rather the nature and content of those limitations.").

The einphasis here is on protecting states and their governments; therefore, a threat to a local government or a single department within a local government should not be enough to justify striking a federal statute when the rest of the state is not affected to the same degree. The claim made by the plaintiff in Romero, for example, that the law enforcement agency of a single local jurisdiction within the state was unable to carry out all its functions, is insufficient to warrant striking the Brady Act. See Romero v. United States, 883 F. Supp. 1076, 1086-88 (1994); see also Mack II, 66 F.3d 1025, 1032 (9th Cir. 1995) (sheriffs Mack and Printz arguing that background checks will "take all of their time or so much of it that they will be unable to perform their regular county duties"). 
tions should a lack of funding become a determinative factor in the Tenth Amendinent analysis. Merely speculative concerns about such an effect should not be sufficient to justify striking down a statute, however. ${ }^{126}$ Rather, the alleged destructive effects would have to be extremely probable, as well as directly linked to the lack of adequate funding.

Several courts have acknowledged hypothetical arguments along these lines in the Brady Act and Motor Voter cases, only to dismiss the suggestion that they are apphicable to the particular case under consideration. As Judge Posner explained in Illinois' Motor Voter appeal:

Illinois advances the ... notion that to make a state administer federal elections fatally compromises state sovereignty. ... We suppose, although it seems extraordinarily unlikely, that Congress might attempt to use the power granted in Article I section 4 to destroy state government, perhaps by constituting all employees of the state full-time federal voting registrars in order to make sure that every eligible federal voter in every state was registered. Maybe if Congress went that far it could no longer be thouglit to be merely altering the state's regulation of federal elections. ${ }^{127}$

But the court quickly rejected the idea that such circumstances were present in the context of the Motor Voter Act: "Evidently the costs of complying with congressional alterations in the times, places, and manner of holding federal elections have not imposed a significant fiscal burden on the states, let alone the kind of staggering burden that might give color to Illinois' argument."128

Similarly, the Ninth Circuit in Mack v. United States ${ }^{129}$ agreed that at some point, a federal statute enlisting the aid of state employees to achieve its objectives could become "so burdensome to the State that it violates the Tenth Amendinent": "Surely the federal government cannot stall the state government in its tracks by imposing all-consuming federal duties on the State's

126. Cf. Helvering v. Gerhardt, 304 U.S. 405,421 (1938) (holding that, to be immune from taxes, a state would have to show that "the burden upon the state function is actual and substantial, not conjectural").

127. ACORN v. Edgar, 56 F.3d 791, 796 (7th Cir. 1995).

128. Id.

129. 66 F.3d 1025 (9th Cir. 1995), cert. granted sub. nom. Printz v. United States, 116 S. Ct. 2521 (1996). 
employees."130 However, the court concluded that the provisions of the Brady Act do not reach that point. ${ }^{131}$ And the Second Circuit, upholding the Brady Act in Frank v. United States, ${ }^{132}$ acknowledged that federal legislation could be "so onerous as to threaten the effectiveness of the States in our federal system," "133 but likewise found that the burden imposed by the Brady Act was not "so significant quantitatively that it rises to the level of a constitutional violation." 134

\section{CONCLUSION}

State officials who bring Tenth Amendment challenges to federal mandates often point to an inadequacy of funding to bolster their claim that the inandate is unconstitutional. But funding should not be a determinative factor in a Tenth Amendinent analysis. Separation of powers principles require Congress, not the courts, to make decisions regarding funding for the execution of duties imposed by federal law. The words of the Court in another context aptly summarize the reasons for rejecting the claim that courts should review Congress' funding decisions: "[the] argument is flawed, not only because it lacks precedential support and is contrary to statements in this Court's opinions, but also because it invites the Court to involve itself in what is clearly a legislative task which the Constitution has left to the political processes."135

Some courts, like those that have heard challenges to the Brady Act, have erred by allowing funding issues to influence their decisions. ${ }^{136}$ Other courts, including the Supreme Court and courts that have heard challenges to the Motor Voter Act, recognize that funding should play no role in the constitutionality determination, but have not pursued a separation of powers analy-

130. Id. at 1032 .

131. See id.

132. 78 F.3d 815 (2d Cir. 1996), petition for cert. filed, 64 U.S.L.W. 3856 (June 13, 1996) (No. 95-2006).

133. Id. at 826 .

134. Id. at 830. Even counsel for the United States in the Mack/Printz appeal to the Supreme Court conceded in its brief that there could be a limit to congressional authority to require states to foot the bill for federal mandates. See United States Brief, supra note 59, at *32-33 \& n.22; see also Printz Transcript, supra note 59, at *42-43 (hypothesizing an unconstitutionally extreme "Perfectly Clean Air Act").

135. Houchins v. KQED, Inc., 438 U.S. 1,12 (1978) (rejecting broadcasting company's claim that First Amendment entitled it to special access to county jail).

136. See supra text accompanying notes 60-69 (discussing Brady Act cases). 
sis. ${ }^{137}$ The rationale set forth in this Note, grounded in the separation of powers, provides courts with a solid reason to decline to consider funding when states urge them to overturn a statute because it is an "unfunded mandate."138 Likewise, this Note provides courts with a basis for rejecting arguments by the federal government that the presence of funding (tied directly to the mandate or not) sliould weigh in favor of upholding a statute. The rule against reviewing Congress' funding decisions should apply regardless of the constitutional clause Congress lias legislated under-whether a highly specific enumerated power like the Article I, Section 4 power to regulate federal elections (used to pass the Motor Voter Act) or a broader power, such as the Commerce Clause (the source of the authority to pass the Brady Act).

While states may believe a rule that prohibits the review of funding decisions makes challenging unfunded mandates more difficult, such a rule does not restrict any of the methods already available for successfully challenging a federal statute. ${ }^{139}$ For instance, an unfunded mandate can always be challenged on grounds that it exceeds the scope of the power under which Congress purports to legislate. ${ }^{140} \mathrm{~A}$ federal law is also unconstitutional if it directly instructs a state legislature to enact particular legislation. ${ }^{141}$ A voluntary condition attaclied to the receipt of federal funds is invalid if it violates a separate constitutional provision, such as the First Amendinent. ${ }^{142}$ And after the Supreme Court announces its decision in Printz, states might also have the argument that a mandate enacted under the Commerce Clause unconstitutionally commandeers state executive officials into implementing and enforcing a federal law. ${ }^{143}$ Furthermore, the states always have the right to lobby Congress for rehef (in the form of fewer mandates or more funding). ${ }^{144}$ But states sliould not rely on the

137. See supra text accompanying notes 35-41 (discussing Motor Voter cases), 70-94 (discussing Supreme Court cases).

138. Given the high financial costs and political implications of federal mandates, see supra notes 3-5, 9-17 and accompanying text, such challenges are bound to continue in the future.

139. See supra notes $19-23$ and accompanying text.

140. See United States v. Lopez, 115 S. Ct. 1624, 1626 (1995) (lolding that Gun-Free Sclrool Zones Act exceeded Congress' Commerce Clause power).

141. See New York v. United States, 505 U.S. 144, 161 (1992) (stating that Congress may not directly compel states to enact a federal regulatory program).

142. See South Dakota v. Dole, 483 U.S. 203, 208 (1987).

143. See supra note 59.

144. The lobbying approach was successful im persuading Congress to pass the Un- 
fact that a federal mandate is madequately funded to support a Tenth Amendment challenge. Other circumstances must render the statute unconstitutional in order for their Tenth Amendment challenge to be successful.

A rule against treating funding as a determinative factor in Tenth Amendment analysis actually protects the states against congressional overreaching. If the presence of federal funding were enough to ensure that a federal mandate would be held constitutional, the federal government could purchase intrusions into state sovereignty and avoid Tenth Amendment problems simply by providimg funding for an otherwise unconstitutional inandate. By refusing to allow states to forfeit aspects of their sovereignty in exchange for federal funds, the rule advocated in this Note protects the states from their own "best intentions." 145 Justice O'Connor, writing for the majority in New York, recognized that "powerful incentives might lead both federal and state officials to view departures from the federal structure to be in their personal interests." 146 She explained that "it is likely to be in the political interest of each individual official to avoid being held accountable to the voters" for certain difficult decisions. ${ }^{147}$ As a result, both state and federal officers might prefer a congressional statute that forced state officials to make those decisions, even though such a statute might be unconstitutional. "The interests of public officials thus may not coincide with the Constitution's intergovernmental

funded Mandates Reform Act (UMRA), Pub. L. No. 104-4, 109 Stat. 48 (codified in scattered sections of 2 U.S.C.), in 1995. UMRA requires federal agencies to prepare statements estimating and explaining the costs of any proposed federal regulations that may require state or local governments to spend, in the aggregate, $\$ 100$ million or more in a single year. See 2 U.S.C. $\$ 1532$ (Supp. I 1995). UMRA also requires the Congressional Budget Office to estimate the costs of new federal mandates being considered by Congress. See id. $\S 658$. However, it remains to be seen how successful UMRA will be in reducing unfunded mandates. The long-term effectiveness of the statute may be limited: "A future Congress seeking the political benefits of a new unfinanced mandate will not be deterred by a prior Congress" anti-mandate commitinent." Zelinsky, supra note 4, at 484 n.2; see also Gillmor \& Eames, supra note 1, at 409 (arguing that a statutory solution to the unfunded mandate problem would be inadequate, and therefore a constitutional amendment is needed to address the problem). Furthermore, it will be difficult, if not impossible, to enforce UMRA; agency actions taken under the act are subject to only limited judicial review, see 2 U.S.C. $\$ 1571$, and the inadequacy of or failure to prepare estimates or statements required by UMRA cannot be used as grounds for invalidating an agency rule. See id. \$1571(a)(3).

145. New York, 505 U.S. at 187.

146. Id. at 182 .

147. Id. at $182-183$. 
allocation of authority. Where state officials purport to submit to the direction of Congress im this manner, federalism is hardly being advanced." 148

State officials are concerned, understandably, about the growing number of unfunded federal mandates, and may initially oppose the rule this Note proposes. In the long run, however, a rule that excludes funding issues from Tenth Amendment analysis protects the states against congressional intrusions into state sovereignty, while allowing states to pursue traditional means of challenging federal statutes on Tenth Amendment grounds.

148. Id. at 183; see also id. at 182. (stating that "[w] here Congress exceeds its authority relative to the States ... the departure cannot be ratified by the 'consent' of state officials"). 